\title{
PROPUESTAS PARA UN NUEVO GOBIERNO JUDICIAL EN CHILE
}

\author{
Proposals for a new government of the judiciary in Chile
}

Andrés Bordali Salamanca*

Resumen: En el trabajo se establecen como premisas de análisis entre otras el que en Chile la regulación orgánica de la judicatura crea las condiciones para que en la designación o en la carrera judicial los jueces se vean sometidos a un poder de mando de la Corte Suprema y en menor medida de las Cortes de Apelaciones y del Ejecutivo. Esta situación afecta la independencia de los jueces en su trabajo jurisdiccional. Se postula de esta manera que el gobierno sobre la judicatura debe ser modificado. Se propone incorporar a la Constitución un órgano del tipo Consejo de la Judicatura para que administre las cuestiones básicas de los tribunales de justicia. Para ello se analiza críticamente cómo ha funcionado este órgano en distintos países: Italia, España y Colombia.

Palabras clave: gobierno judicial, tribunales - Consejo de la Judicatura - Consiglio Superiore della Magistratura - Consejo General del Poder Judicial - Consejo Superior de la Judicatura.

Abstract: The paper departs from the analytical premise that the current regulation of the judiciary in Chile establishes conditions that subject judges to the commanding power of the Supreme Court and to lesser extent of the appeal courts. Particularly important at the time of appointments and promotions, this affects the independence of judges in their judicial work. It is suggested that the government on the judiciary must be modified. It is proposed to incorporate into the Constitution a body with the characteristics of a Council of the Judiciary to administer the basic issues of the courts. With this purpose it is critically discussed how this kind of body has worked in different countries, namely Italy, Spain and Colombia.

Keywords: Judicial governance - courts - Consiglio Superiore della Magistratura Consejo General del Poder Judicial - Consejo Superior de la Judicatura.

* Abogado, Doctor en Derecho, Profesor de Derecho Procesal Universidad Austral de Chile, Valdivia, Chile. Dirección electrónica: abordali@uach.cl

Este trabajo forma parte del proyecto de investigación financiado por el programa Fondecyt "El gobierno de un Poder Judicial difuso", N ${ }^{\circ}$ 1120232, del que el autor de este trabajo es su investigador responsable.

Este artículo fue recibido el 23 de septiembre de 2014, siendo aprobada su publicación el 11 de diciembre de 2014. 


\section{INTRODUCCIÓN}

La oralidad introducida en la mayoría de los procedimientos jurisdiccionales chilenos ha comportado en alguna medida realizar modificaciones orgánicas centradas principalmente en organizar de una manera adecuada la oficina judicial. Asimismo, se han realizado cambios en el modo como se atiende al público y como se administran las causas ingresadas al tribunal, entre otros aspectos. Desde luego todas estas reformas han comportado realizar importantes innovaciones en los sistemas informáticos y computacionales para un mejor servicio y trabajo jurisdiccional.

Sin embargo, existe otro aspecto organizacional que no ha sido objeto de reformas. Me refiero fundamentalmente al tema de la gestión del personal judicial en lo referente a nombramientos, carrera judicial, traslados y control disciplinario de los jueces. Estos aspectos suelen englobarse en el concepto de gobierno o administración judicial.

En materia de gobierno de la judicatura, Chile ha caminado por senderos muy diferentes a los de la mayoría de los países pertenecientes a la tradición de derecho continental. En estos la evolución ha consistido en sustraerle la dirección de la judicatura al Poder Ejecutivo (Ministro de Justicia) y conferir dicha dirección a órganos conocidos como Consejos de la Judicatura. A las Cortes Supremas se les ha reservado alguna parcela de ese gobierno judicial.

En Chile es la Corte Suprema principalmente y las Cortes de Apelaciones en menor medida las que han desarrollado esta labor de dirección y gestión judicial. Marginalmente el Presidente de la República también tiene algunas competencias en materia de gobierno judicial.

La dirección de la judicatura radicada en el Ejecutivo que (re) instauró Napoleón en Francia a comienzos del siglo XIX, ${ }^{1}$ comportó una evidente merma a las necesidades de independencia judicial y de separación de poderes que la doctrina más ilustrada, con Montesquieu a la cabeza, reclamaba desde un buen

1 Comentaba a fines del siglo XIX Lodovico Mortara que con Napoleón se daba un contrasentido, pues al ser impulsor de la codificación se lo ve como un artífice de un derecho igual, universal, sin árbitros y conocido por todos. Instituyó, agrega este autor italiano, una magistratura docta y respetada por el pueblo. Pero su obra -sostiene- no fue sino la de un déspota ilustrado. La magistratura que él organiza en Francia tiene todas las características de aquella germánica. Se trata de una judicatura donde su independencia no fue nunca asegurada con los cambios políticos que en ese momento se llevaron a cabo. Sorprende a su juicio que en Francia en esta época no se haya sabido asignar a la autoridad judicial el oficio y la importancia que es necesario para la garantía jurídica de la sociedad y para la conservación del equilibrio de los derechos. Vid. MORTARA (1992), pp. 47 y 48. 
tiempo. ${ }^{2}$ Esos aires más independentistas de la judicatura solo vieron luz real y de manera permanente en Europa luego de la segunda guerra mundial con la creación de los Consejos de la Judicatura. Francia, Italia y luego Portugal, España, Holanda, Bélgica, Irlanda, Dinamarca, Polonia, Bulgaria, Rumania, entre otros países europeos, los crearon. En nuestra región sudamericana, Venezuela, Brasil, Argentina, Bolivia, Perú, Paraguay, Colombia y Ecuador, también los crearon. México, Guatemala, El Salvador y República Dominicana en América del Norte y Central. Esos consejos supusieron quitarle la influencia que el Ejecutivo y las Cortes Supremas ejercían sobre la judicatura al controlar la nominación, traslado, ascenso y destitución de los jueces.

Al contrario de esa experiencia comparada, Chile en su historia republicana casi siempre ha visto radicada la dirección de la judicatura en uno de sus tribunales, como lo es la Corte Suprema. En esa labor colaboran también las Cortes de Apelaciones. El Ejecutivo por intermedio del Presidente de la República ha tenido históricamente alguna injerencia en esa administración, la que hoy en día se refiere a la asignación presupuestaria del funcionamiento de la judicatura. También le corresponde nombrar a los magistrados y fiscales judiciales de las Cortes de Apelaciones y a los jueces letrados, a proposición de la Corte Suprema y de las Cortes de Apelaciones, respectivamente; a los miembros del Tribunal Constitucional que le corresponda designar; y a los magistrados y fiscales judiciales de la Corte Suprema, a proposición de dicha Corte y con acuerdo del Senado (artículo $32 \mathrm{~N}^{\circ} 12$ Constitución Política de la República, en adelante CPR).

Por otra parte, pero con menor impacto, le corresponde al Presidente de la República velar por la conducta ministerial de los jueces y demás empleados del Poder Judicial y requerir, con tal objeto, a la Corte Suprema para que, si procede, declare su mal comportamiento, o al Ministerio Público, para que reclame medidas disciplinarias del tribunal competente, o para que, si hubiere mérito bastante, entable la correspondiente acusación (art. $32 \mathrm{~N}^{\circ} 13 \mathrm{CPR}$ ). Hoy ello se traduce en que el Presidente de la República puede requerir a la Corte Suprema o al Ministerio Público para que se haga efectiva la responsabilidad disciplinaria o penal de los jueces. El Ejecutivo por sí solo no puede adoptar alguna medida disciplinaria contra los jueces y desde luego no puede aplicar una sanción penal sobre ellos.

En el derecho chileno el Ejecutivo, a diferencia del sistema europeo del siglo XIX y de la primera mitad del siglo XX, ni antes ni hoy ha tenido una injerencia importante en la organización y dirección de la judicatura. Tiene sí en la actualidad y lo ha tenido históricamente cierta participación en la designación de los jueces, dando paso a una "politización" en el sistema de nombramientos y

\footnotetext{
${ }^{2}$ Una estructura de Poder Judicial no burocrático y menos jerárquico se vio con la Ley sobre Organización de la Justicia del 16 - 24 de agosto de 1790. Con Napoleón esa organización judicial cambió radicalmente. Vid. DENTI (2004), pp. 17 y 19.
} 
ascenso de los jueces. En el caso de los ministros y fiscales de la Corte Suprema esa "politización” se traslada también al Senado de la República.

Dejando de lado el problema de los nombramientos de los jueces y ministros por el Presidente de la República y del Senado en algunos casos (Corte Suprema), hay que señalar que el mayor poder de dirección de la judicatura lo ha tenido siempre y lo conserva aún la Corte Suprema de Justicia y en menor medida las Cortes de Apelaciones. Es por este motivo que los problemas de afectación de la independencia judicial por otros poderes del Estado, especialmente del Ejecutivo, como sucedía en los países europeos y algunos países latinoamericanos señalados, en Chile no se ha dado con la misma intensidad. ${ }^{3}$ La afectación más relevante a la independencia judicial se verifica al interior de la estructura judicial chilena.

Asumiendo de esta manera que en nuestro país los problemas principales del funcionamiento de la jurisdicción están referidos a un tema de independencia interna, y marginalmente a una cierta "politización" en el nombramiento de los jueces, surge la pregunta si la solución a este problema pasa por crear un órgano de dirección de la judicatura del tipo Consejo de la Judicatura, que reemplazaría a la Corte Suprema y a las Cortes de Apelaciones en estas funciones, así como al Presidente de la República en sus escasas funciones de gobierno o dirección judicial.

Los Consejos de la Judicatura no han estado exentos de crítica. ${ }^{4}$ Se habla en algunos países que los han instaurado de una "politización" del sistema de gobierno judicial. En otros casos se habla de ineficiencia en la actuación del órgano. Es por ello que en este trabajo se quiere analizar cuál es la evaluación existente en el derecho comparado de cómo funcionan estos Consejos de la

\footnotetext{
${ }^{3}$ En Chile además de la intervención política en el nombramiento y ascenso de los jueces, ha existido un problema que no se lo puede designar como intervención del Ejecutivo en el ejercicio jurisdiccional, sino que consiste en un diseño legal de algunos tribunales de justicia que están insertos dentro de la Administración del Estado o del Gobierno, lo que afecta al imparcial desarrollo de la función jurisdiccional. Este diseño legislativo ha sido avalado por la Corte Suprema y por el Tribunal Constitucional. Históricamente esta ha sido la situación del Director Regional del Servicio de Impuestos Internos al que la ley consideraba como el tribunal competente para conocer de las reclamaciones de los contribuyentes. Por otra parte, asoman críticas el día de hoy sobre el diseño legislativo de ciertos tribunales especiales de lo contencioso administrativo, por tener el Ejecutivo cierto control en la designación de los jueces y en su operar. Así sucede por ejemplo con la designación de los ministros de los tribunales ambientales, donde el Ejecutivo participa doblemente en esa designación; por sí mismo y por el Sistema de Alta Dirección Pública, entidad que depende del Ejecutivo. Respecto de los Tribunales Tributarios y Aduaneros, se puede criticar cierta dependencia técnica respecto del Ministerio de Hacienda.

${ }^{4}$ Juan Enrique Vargas señala que los Consejos de la Judicatura en la región latinoamericana son objeto hoy en día de serios cuestionamientos. Esa crítica ha llevado a países como Venezuela a suprimirlo de su ordenamiento jurídico y a otros países como México y Argentina a introducirle importantes cambios. Vid. VARGAS (2007), pp. 108 y 109.
} 
Judicatura. De este modo, se analizará la experiencia de tres países que han instaurado el órgano. Dos europeos (Italia y España) y uno latinoamericano (Colombia). Se ha elegido a estos tres países por tener una clara afinidad cultural con el nuestro. En el caso de España e Italia en particular, se los ha elegido como referentes comparativos porque nuestros Derecho Constitucional y Procesal tienen claras influencias en los ordenamientos y la doctrina de esos países. En el caso de Colombia se lo ha elegido por su relativa cercanía cultural y por tener un nivel de desarrollo similar al chileno. Con esas experiencias comparadas evaluaremos si es oportuno introducir un órgano de este tipo en nuestro sistema jurídico y, si el análisis fuese positivo, cómo debería realizarse la incorporación de tal órgano.

\section{Premisas para un correcto funcionamiento de la Jurisdicción: Análisis de su existencia en el derecho chileno}

Para que el trabajo jurisdiccional sea realizado de manera correcta en el marco de un Estado democrático de derecho respetuoso de los valores de la imparcialidad en la aplicación de la ley y de seguridad jurídica, deben concurrir entre otros los siguientes supuestos:

a) Los tribunales deben estar sometidos a la ley y solo a la ley (o al derecho si se quiere). Desde otra mirada, los tribunales deben aplicar a los casos que les son sometidos la ley y solo la ley. Los tribunales no pueden fallar los casos en atención a sus propios intereses, ni a lo que convenga al gobierno de turno o a los demás poderes políticos ni a ningún sector económico o social del país;

b) Los jueces deben ser libres para interpretar la ley aplicable a un caso concreto, sin que se vean expuestos a presiones ni represalias. Un juez no puede ser sancionado ni mal calificado por el modo como interpreta la ley, en la medida en que su interpretación no sea considerada expresión de una voluntad manifiesta de fallar contra ley. Tampoco puede recibir presiones desde los poderes que tienen a su cargo la gestión de la carrera judicial.

c) Deben existir incentivos adecuados para estimular el trabajo de excelencia de los jueces. La administración judicial debe permitir distinguir entre buenos y malos jueces y premiar a los primeros o castigar a los segundos;

d) Debe existir una adecuada coordinación entre las decisiones de los diferentes tribunales del país en aras de la seguridad jurídica y del principio de igualdad constitucional. ${ }^{5}$

Estas premisas no se cumplen en el sistema jurídico chileno. Ello está dado fundamentalmente por el sistema de dirección del Poder Judicial y de la judicatura en general, en manos de la Corte Suprema y en menor medida de las Cortes de

\footnotetext{
${ }^{5}$ No se trata de instaurar un sistema de precedentes vinculantes, algo ajeno a la tradición y al sistema de fuentes del derecho constitucional chileno, sino un sistema flexible de precedentes que los hace, prima facie, vinculantes, pero respecto de los cuales, si se justifica, los jueces pueden apartarse.

Sobre este aspecto véase BORDALÍ (2013), p. 626 y ss.
} 
Apelaciones, que afecta la independencia de los jueces inferiores. Por otra parte, estas premisas tampoco se cumplen por las presiones o señales que los jueces reciben desde el mundo político que participa en la carrera judicial o ascenso de ellos. Vamos a analizar estos dos ámbitos por separado.

\section{Afectación de la independencia de los jueces dentro de la estructura judicial}

En trabajos anteriores he señalado que el sistema de organización y de dirección de la judicatura chilena genera las condiciones para que los jueces no se sientan completamente independientes para conocer y fallar los casos a ellos sometidos. ${ }^{6}$ La diferenciación no funcional, sino orgánica o administrativamente jerárquica entre tribunales dificulta que los jueces se sientan sometidos solo a la ley como exige el paradigma del Estado de Derecho moderno y contemporáneo.

En Chile existe una organización judicial tal que impulsa o puede impulsar a que los jueces inferiores apliquen la ley a un caso concreto considerando la interpretación de esa ley que al respecto ha realizado o podría realizar tanto la Corte Suprema como las Cortes de Apelaciones, para así mantenerse en el cargo de juez o para hacer carrera judicial. Esa consideración de cómo han interpretado y aplicado la ley los jueces superiores, lo que no se produce necesariamente por la persuasión argumentativa o la auctoritas de esos jueces superiores, podría condicionar a los jueces inferiores a interpretar la ley de una manera incorrecta o contraria a su real comprensión. Todo ello termina por concentrar en los tribunales superiores y especialmente en la Corte Suprema el ejercicio jurisdiccional, lo cual se contrapone a una concepción difusa y desconcentrada del poder jurisdiccional que consagra la Constitución en el artículo 76.

El problema que se da entonces con la judicatura chilena es de sometimiento de los tribunales inferiores respecto de sus superiores, afectándose así la independencia de los primeros y, en definitiva, restándoles imparcialidad a esos tribunales, entendida esta como vinculación a la ley y solo a la ley en los casos en que son llamados a conocer y resolver.

\section{Presiones a los jueces desde el mundo político que determinan el éxito de su carrera judicial}

Es un hecho de público conocimiento que cada vez que corresponde la nominación de un ministro de la Corte Suprema comienza una actividad política dentro del poder Ejecutivo y en el Senado para definir quién deberá ocupar el cargo de ministro del máximo tribunal. Se analizan por parte del Gobierno y los

\footnotetext{
${ }^{6}$ Véase últimamente BORDALÍ (2013).
} 
parlamentarios en este procedimiento si los candidatos propuestos por la Corte Suprema son progresistas o conservadores, si han aplicado o no la ley de amnistía en los procesos por derechos humanos, si tienen una "sensibilidad" cercana a uno de los bloques políticos mayoritarios en el país, entre otros aspectos. Es decir, se procede a realizar un análisis estrictamente político. En este procedimiento se negocia entre la mayoría y la minoría política y se termina realizando un turno binominal de un ministro de la Corte Suprema nombrado por cada uno de los dos grupos políticos mayoritarios en nuestro país. Ello claramente significa introducir un elemento político y no técnico en la designación de los ministros de la Corte Suprema. Es evidente que si tanto el Ejecutivo como el Congreso Nacional tienen la competencia discrecional para designar a un juez de la República, operarán normalmente criterios políticos en esa designación.

En definitiva, los jueces que quieren postular a un cargo de mayor jerarquía reciben señales o si se quiere directrices que provienen de los poderes políticos dominantes, lo que condiciona o podría condicionar su ejercicio jurisdiccional. ${ }^{7}$

Ahora bien, de manera previa a las instancias políticas, todos los candidatos a ocupar una plaza judicial tienen que cumplir con un trámite que no lo prevé la Constitución ni la ley y que consiste en una entrevista personal. Este trámite consiste en que los candidatos deben pedir una audiencia con los ministros de la Corte Suprema o de las Cortes de Apelaciones, según cual sea el tribunal al que postulen, en la que se presentan ante los referidos ministros para que estos los conozcan. Como este trámite no está regulado en la ley, se desconoce mayormente en qué consiste la entrevista entre candidato y el ministro. Como sea, parece ser que hay un espacio amplio para la subjetividad y discrecionalidad en esta instancia. Y lo peor de todo, parece ser una expresión de poder y sometimiento de un futuro juez hacia quienes lo proponen.

\footnotetext{
${ }^{7}$ Este tema amerita una discusión más profunda y de más largo aliento que debe ser realizada en otra sede. Sin embargo, se debe señalar que en el análisis de los méritos de los candidatos se debe evitar realizar un juicio que implique una revisión de las sentencias de los jueces, porque ello comporta una especie de censura a su trabajo y, por otro lado, condiciona el trabajo de los jueces que hacia el futuro desean llegar al máximo tribunal. Es evidente que las fuerzas políticas evalúan la sensibilidad o cercanía política del candidato, pero no parece aconsejable un examen en concreto de cómo han fallado hacia el pasado los candidatos al cargo. Más aconsejable se muestra realizar una audiencia pública ante el Senado donde el candidato pueda ser interrogado sobre su concepción del derecho, de los derechos fundamentales, aplicación e interpretación del derecho, fuentes del derecho vigentes, etc. Todos esos temas, que tienen una dimensión ideológica y política importante dentro de los espacios de discrecionalidad y creación judicial del derecho, pueden ser valorados por los actores políticos en su lógica de ejercicio del poder, pero su análisis y valoración es más tenue y sutil frente a la alternativa de escrutar cómo han fallado las causas en el pasado. Se trata sobre todo de formas que tienen impacto en el sistema de separación de poderes y en la legitimación del procedimiento de creación de legalidad.
} 
Se debe agregar que para todos los cargos judiciales, el candidato, una vez que se ha entrevistado con los ministros de las Cortes y luego ha sido incluido en la terna o quina según corresponda, tiene que hacer gestiones ante el Ministerio de Justicia con la persona encargada de los nombramientos judiciales. Esa persona responsable de tal función recibe llamados telefónicos y cartas de diputados, senadores, intendentes, y otras personas del mundo político, que apoyan la postulación del candidato, con lo cual el apoyo político y personal del candidato es indispensable para el éxito de su postulación. Nuevamente estamos frente a una manifestación de politización y discrecionalidad en la designación de los jueces chilenos.

De este modo, tenemos en Chile por un lado un sistema judicial que propende hacia la concentración no voluntaria ni deseada de la actividad jurisdiccional en manos de la Corte Suprema y por otro, un sistema de gobierno y administración de la judicatura bastante "politizado" y con mucha discrecionalidad en la designación de los jueces y su promoción.

Lo anterior debe llevarnos a buscar un sistema de gobierno o dirección de la judicatura que disminuya lo más posible la intervención de determinados tribunales de justicia sobre el trabajo de otros, así como los condicionamientos políticos para acceder a un cargo judicial. Asimismo debe evitarse la excesiva discrecionalidad en la elección de los candidatos. Chile no está en el mejor pie posible en esta materia y los ciudadanos se merecen una mejor organización y dirección judicial.

\section{Alternativas al gobierno o administración de la jurisdicción por la Corte Suprema y las Cortes de Apelaciones}

Cuando se habla de tipos de gobierno o administración de la judicatura se está poniendo énfasis en sistemas regulados por el derecho que se refieren en lo esencial a la designación, promoción, traslado, sanción y remoción de los jueces, así como su capacitación o formación, entre otros aspectos.

Observando los países de nuestro entorno, se puede constatar que en los países europeos se pasó de encomendar el gobierno o administración judicial del Ministerio de Justicia a órganos del tipo Consejos de la Judicatura. Ello acaece recién después de la segunda guerra mundial. Hoy en día el modelo de los Consejos de la Judicatura se ha exportado a la mayoría de los países latinoamericanos. De este modo el gobierno de la judicatura en manos de un órgano del tipo Consejo de la Judicatura es mayoritario en Europa y también en latinoamérica.

El otro modelo de gobierno o administración judicial corresponde al de Estados Unidos de Norteamérica. En este país todas las cortes federales están sujetas a las directrices de la Conferencia Judicial, presidida por el Presidente de la Corte Suprema (Chief Justice). La Conferencia Judicial está integrada exclusivamente 
por jueces (el Presidente de la Corte Internacional de Comercio, los presidentes de las Cortes de Apelaciones de cada circuito y un juez de distrito por cada circuito judicial, elegidos por mayoría de votos de los jueces del mismo). Este organismo carece de atribuciones en los nombramientos judiciales. Sus facultades se refieren a la adecuada gestión administrativa de las cortes, a la recolección de información acerca del desempeño judicial y a la fiscalización, mediante comités ad hoc, de la buena conducta judicial a nivel federal (aunque sin potestad de ordenar la remoción de jueces federales). ${ }^{8}$

Junto a la Conferencia Judicial existen otros órganos de apoyo en la gestión y administración judicial, como la Administrative Office of The United States Courts.

Analizando críticamente estos sistemas, hay que señalar que aquél que somete a los jueces a la administración por parte del Ministro de Justicia puede evitar que unos jueces influyan indebidamente sobre el trabajo de los otros, pero evidentemente incurre en un problema mayor que significa someter a los tribunales al control político del Ejecutivo, afectándose la independencia externa de los jueces. Si el poder ejecutivo designa, promueve, traslada y destituye a los jueces, estamos en presencia del fin del Estado de Derecho. Esta es una situación que debemos evitar a toda costa y a la que Chile, afortunadamente, no ha estado mayormente expuesta en su vida republicana. No creo que se necesite argumentar más para sostener que este sistema que primó en Europa continental durante todo el siglo XIX y hasta la Segunda Guerra Mundial, es el peor sistema de gobierno o administración judicial. En él la independencia de los jueces respecto del poder político se termina.

De esta manera, los sistemas a seguir en nuestro ordenamiento jurídico deben consistir en una versión de la Conferencia Judicial estadounidense o en el de los Consejos de la Judicatura europeos y latinoamericanos.

El sistema de la Conferencia judicial se muestra mejor que el nuestro, debido a que en él participan distintos estamentos judiciales con posibilidades de elección de sus integrantes por los propios jueces. Se muestra de esta manera más democrático y representativo que el sistema chileno. Por otra parte, sus facultades de administración parecen ser más limitadas y menos discrecionales que las que tiene la Corte Suprema chilena.

No tengo por ahora las herramientas necesarias para realizar una evaluación crítica más completa de cómo funciona este órgano, pero este sistema parece responder a una lógica del Estado federal que es ajena a nosotros y por ello no creo que se adecue mayormente a lo que necesita la organización judicial de

${ }^{8}$ Cfr. United State Code, Title 28, Section 331. 
nuestro país. Por otra parte, parece funcionar de una manera más coherente en un sistema de precedentes como el estadounidense. ${ }^{?}$

En todo caso, no es objeto de este trabajo realizar un análisis crítico sobre el funcionamiento de la Conferencia Judicial estadounidense. Por ello me limitaré a informar de su existencia y de que constituye una alternativa al sistema chileno y al europeo y latinoamericano de dirección judicial, pero que por las complejidades del Estado Federal y del sistema político estadounidense quizás impidan o desaconsejen una instauración en nuestro país. Chile tiene un tipo de judicatura más parecida a la que tienen los países europeos y latinoamericanos y por ello creo que puede ser más fructífero centrarse en un análisis crítico de los Consejos de la Judicatura.

\section{Experiencias comparadas de Consejos de la Judicatura: El caso de Italia, España y Colombia}

\section{E1 Consiglio Superiore della Magistratura}

En el caso de Italia, el Consiglio Superiore della Magistratura (en adelante CSM) tiene reconocimiento constitucional (artículo 104 y siguientes). Se trata de un órgano que introdujo la Constitución de 1947, pero que tiene antecedentes legislativos anteriores. Es así que desde el año 1880 se estableció en Italia un órgano con poderes consultivos, presidido por el Ministro de Gracia y Justicia, que tenía competencia sobre el estatus de los jueces. ${ }^{10} \mathrm{La}$ creación de un órgano de este tipo era reclamada por alguna doctrina italiana desde comienzos del siglo XIX. ${ }^{11}$ Sin embargo, antes de la Constitución de 1947, sin perjuicio de la existencia de este organismo consultivo, el mayor protagonismo sobre la administración de la judicatura recaía en el Ministro de Justicia y también en la Corte de Casación.

Después de la primera experiencia de fines del siglo diecinueve de un órgano con algunas competencias de gobierno de la judicatura, el CSM fue incorporado en la Constitución italiana de 1947 luego de un amplio debate de los constituyentes sobre cómo potenciar y facilitar tanto la independencia externa como interna de los jueces italianos.

\footnotetext{
${ }^{9}$ Con todas las prevenciones sobre el funcionamiento del precedente estadounidense que formula Michele Taruffo, cuando expresa que no hay que entender al precedente en dicho país como absolutamente vinculante. Vid. TARUFFO (2001), p. 98.

10 Vid. BOnifacio y GiacobBe (1986), p. 41.

${ }^{11}$ Como era el caso de autores como Romagnosi y Mortara. Vid sobre este punto ANDRÉs (2007).
} 
Para un sector de la doctrina, ${ }^{12}$ el CSM puede ser definido como órgano de gobierno de la magistratura con relevancia constitucional para la tarea esencial en un Estado de Derecho de garantizar la independencia y autonomía de los jueces. Otros autores ponen atención también en otros destinatarios del órgano. Se trata de la tutela que los ciudadanos obtendrían del CSM en cuanto este serviría como garantía para obtener una justicia imparcial y un correcto comportamiento y trato por parte de los jueces. ${ }^{13}$

Es necesario dejar en claro que no estamos frente a un órgano jurisdiccional ni menos, por tanto, que sea el vértice organizativo de la jurisdicción. ${ }^{14}$ Tampoco se está frente a un órgano que tenga relevancia política. Esto quiere decir que entre sus competencias no tiene aquella referida a elaborar actos dirigidos a la obtención de un interés general, que en cuanto normativos, se impondrían a los jueces en el desarrollo de su función jurisdiccional. Si no es un órgano jurisdiccional ni de relevancia política en el sentido que no tiene la dirección política o de gobierno de la sociedad, sus funciones se asimilan a las de tipo administrativo.

En general la doctrina italiana está conteste en esta naturaleza administrativa del CSM. ${ }^{15}$ En ocasiones se habla de un órgano técnico titular de poderes de alta administración que tanto la Constitución como la ley le confieren. ${ }^{16}$ Nos referimos a los actos mayoritarios y trascendentales del CSM que dicen relación con la nominación de los jueces, asignación de las sedes o de funciones, traslados, promociones y todo acto relativo al estatus de los jueces. Sin embargo, entre otras funciones, ${ }^{17}$ el CSM adopta decisiones en materia disciplinaria de los jueces las que son consideradas decisiones jurisdiccionales. Esta separación de funciones tiene importancia especialmente respecto del control de los actos del CSM. Los primeros, en cuanto administrativos, son controlables ante los tribunales de lo contencioso administrativo. Los segundos, jurisdiccionales, son recurribles ante la Corte de Casación. ${ }^{18}$

12 Vid. Gustapane (1999), p. 316

13 Vid. BALBONI (2006), p. 63.

14 Vid. SILVESTRI (2002), p. 285.

15 Vid. PiZzorusso (2009), p. 15; SERGES (2001), p. 44; SORRENTINO (2009), p. 189; VALlefuOCO (2013), p. 158.

16 Vid. ZANON (2006), p. 12.

${ }^{17}$ Michele Vallefuoco clasifica en cuatro las funciones del CSM: administrativas, disciplinarias, relativas a la organización del órgano y funciones referidas a la actividad de propuesta de opiniones. Entre las organizativas pone como ejemplo la elección del Vicepresidente, formación de las comisiones, etc. Entre las últimas señala el hacer propuestas sobre modificación de las circunscripciones judiciales y sobre todo lo que se refiera a los servicios relativos a la justicia. Puede además dar opiniones sobre proyectos de ley que se refieren al ordenamiento judicial y la administración de justicia. Cfr. VALLEFUOCO (2013), p. 158.

18 Vid. BARTOLE (2008), p. 67. 
La incorporación del CSM a la Constitución italiana de 1947 fue para extraer a la judicatura de la influencia del Ministro de Gracia y Justicia. De esta manera, los constituyentes italianos decidieron transferir funciones esenciales que tenía el poder Ejecutivo al CSM, para así favorecer la autonomía del orden judicial. ${ }^{19}$ Sin embargo, existe mucha discusión en Italia sobre los conceptos de autonomía y autogobierno de la magistratura.

La propuesta de autonomía judicial entendida como autogobierno es rechazada por algunos en cuanto puede entenderse como una gestión que podría velar por intereses diferentes de aquellos intereses generales del Estado y del ordenamiento jurídico. Dicho de otro modo, se señala que el CSM no puede velar por intereses propios. En este sentido, a veces se propone hablar de órgano de gobierno administrativo de los jueces. En otras ocasiones se habla de un rol de administración de la jurisdicción que cumpliría el $\mathrm{CSM}^{20}$ Con esta referencia se pretende poner énfasis en que no estamos frente a un órgano de dirección política, así como tampoco es un órgano de representación de los intereses corporativos de los jueces. ${ }^{21}$ Se trata de un órgano introducido en la Constitución para garantizar la independencia judicial. Este órgano tiene encomendada la realización de las principales actividades administrativas instrumentalmente necesarias para el ejercicio imparcial de la jurisdicción. ${ }^{22}$

En este mismo sentido, un sector de la doctrina propone entender por autonomía de la magistratura la gestión de esta por el CSM mediante las competencias que tanto la Constitución y las leyes le asignan al órgano. Esta gestión no excluye la regulación ni la intervención del legislador en temas referidos al trabajo jurisdiccional, así como tampoco a las competencias que en materia de orden jurisdiccional el ordenamiento jurídico pueda conferir al Ministro de Justicia. Asimismo, como muchos de los actos del órgano de administración de la magistratura son actos administrativos, para su validez externa tienen que cumplir con los requisitos de validez de estos (por ejemplo, firma del Presidente de la República y del ministro respectivo). Se pone en evidencia por algunos que en un Estado de Derecho los actos del CSM no pueden quedar sin control jurisdiccional. ${ }^{23} \mathrm{El}$ CSM no está fuera del Estado y como tal debe estar sujeto a los controles que el sistema jurídico contemple. De igual modo debe relacionarse con los otros órganos del Estado en una lógica de controles recíprocos y de balance de poderes.

19 Vid. Pizzorusso (2009), p. 15.

20 Vid. SERGES (2001), p. 44.

21 Vid. ANDRÉS (1999), p. 20.

22 Vid. PiZZOrusso (1999), p. 102.

23 Vid. ZANON (2006), p. 20. 
Para otros autores se debe hablar derechamente de autogobierno antes que autoadministración. ${ }^{24} \mathrm{Y}$ la referencia al autogobierno dice relación entre otros aspectos sobre la capacidad de ejecutar actos que no correspondan a expresas competencias conferidas por la ley, pero que estén orientados a garantizar la independencia e imparcialidad de los jueces. Se hablaría así de "poderes implícitos" del CSM. De esta manera se ha discutido en Italia si ante posibles ataques o amenazas recibidas por un juez, el CSM podría realizar una declaración en defensa del juez afectado, algo que la ley no prevé expresamente. La jurisprudencia administrativa se ha decantado por una tesis negativa al considerar que el CSM tiene un elenco cerrado o taxativo de atribuciones. ${ }^{25}$

En esta misma discusión sobre la posición institucional del CSM se ha debatido sobre la capacidad normativa del Consejo. Partiendo de la base de la reserva de ley que le reconoce expresamente la Constitución al Parlamento, ello impediría que el CSM dicte actos normativos de eficacia general. Solo podría dictar actos que tengan impacto al interior de la magistratura y nunca sobre terceros. ${ }^{26}$

Dicho lo anterior, hay que agregar que para acentuar que no se trata de un órgano de autogobierno de los intereses de los jueces, el constituyente italiano evitó encargar la administración del orden judicial a un órgano formado solo por jueces. Pero este aspecto fue objeto de una confrontación en su momento entre distintas tesis. Por un lado existió un grupo de constituyentes que con la idea de robustecer la autonomía de la magistratura ideaba al CSM como un órgano compuesto exclusivamente por jueces y presidido por el Primer Presidente de la Corte de Casación. Esta tesis más autonomista era liderada entre otros por Piero Calamandrei. ${ }^{27}$

La otra tesis liderada por Leone consideraba un diseño donde el CSM estaría integrado de manera igualitaria entre jueces y miembros designados por el Parlamento y presidido por el Ministro de Justicia. Con esta segunda tesis se intentaba conectar la judicatura con los otros poderes del Estado.

Se llegó finalmente a un acuerdo donde se logró reforzar el principio de autonomía de la magistratura respecto de los otros poderes del Estado, ya sea por la prevalencia numérica de los componentes togados, o bien por la presidencia confiada a la figura institucional del Presidente de la República, que

24 Vid. BALBONI (2006), p. 60.

${ }^{25} \mathrm{El}$ Tribunal Administrativo de la región de Lazio señaló en sentencia de 20 de abril de $1998 \mathrm{n}^{\circ}$ 1329, que el CSM es un órgano administrativo y como tal solo puede ser titular de poderes expresamente atribuidos por ley.

26 Vid. ZANON (2006), pp. 14 y 15.

27 Vid. Gustapane (1999), pp. 113 y ss. 
más que ningún otro poder representa con la máxima imparcialidad y neutralidad la unidad del Estado. ${ }^{28}$

En la propuesta definitiva ideada por los constituyentes italianos, además de formar parte del CSM el Jefe de Estado, lo integran miembros nombrados por el Parlamento. Es decir, existe una componente que se acostumbra a definir como laica cuyo fin principal es conectar la autonomía de la magistratura con la necesaria vinculación que el orden judicial debe tener con los demás poderes del Estado. Dicho de otra manera, se vio de manera positiva que el órgano que administra la magistratura tuviese conexiones con el mundo de la política. ${ }^{29}$ De esta forma se evita que el CSM se transforme en autorreferencial, corporativamente replegado en sí mismo y privado de conexiones con el ordenamiento constitucional. ${ }^{30}$

En definitiva, el CSM es un órgano de relevancia constitucional que garantiza la autonomía del orden judicial en estrecha conexión con los otros poderes del Estado mediante una articulación representativa mixta, en parte institucional y en parte electiva, en el que el elemento togado es preponderante respecto de la otra componente (laica). Tanto los componentes laicos como los togados pueden ser miembros de pleno derecho o bien elegidos. Entre los de pleno derecho están: el Presidente de la República; ${ }^{31}$ el Presidente del Tribunal Supremo y el Fiscal General del Tribunal Supremo. Respecto de los elegidos, la Constitución no establece su número. Es la ley (ley n 44/2002) la que establece su número y proporción. De los veinticuatro miembros que dispone la ley, dieciséis $(2 / 3)$ son togados, elegidos entre todos los jueces ordinarios pertenecientes a las distintas categorías; ${ }^{32}$ ocho $(1 / 3)$ deben ser elegidos por el Parlamento en sesión conjunta, entre profesores ordinarios (máxima categoría del escalafón universitario) de universidades en materias jurídicas y abogados con quince años de ejercicio de la profesión.

Respecto de los miembros togados, estos son elegidos individualmente por candidaturas sostenidas por a lo menos veinticinco jueces y no más de cincuenta. Cada elector recibe tres papeletas por cada uno de los tres colegios nacionales y vota por un solo magistrado para cada categoría de ellos.

28 Vid. VALLEFUOCO (2013), pp. 136 y 137.

29 Vid. ZANON (2006), p. 7.

${ }^{30}$ Vid. ZANON (2006), p. 7. A juicio de Giorgio Rebuffa, el CSM no es un verdadero y propio órgano de autogobierno de la magistratura, sino que es un órgano de conexión entre los jueces y los poderes políticos representativos. Cfr. REBUFFA (1993), p. 92.

${ }^{31}$ La presencia del Presidente de la República a la cabeza del CSM es visto como expresión de la relevancia constitucional del rol de garantía que cumple el órgano. El Presidente de la República de Italia representa la unidad de la Nación. En este sentido, su rol es el de asegurar la independencia del orden judicial respecto de las partes políticas, protegiéndolo de interferencias indebidas. Vid. BARTOLE (2008), p. 62.

32 Dos miembros deben ser elegidos entre magistrados del Tribunal Supremo, cuatro entre magistrados que ejercen funciones de mérito y diez entre magistrados que ejercen funciones de instrucción. 
Esta composición del CSM no siempre ha sido así. En primer lugar, cuando después de diez años de su consagración constitucional se logró finalmente que el órgano entrara en funcionamiento (Ley $\mathrm{N}^{\circ} 195$ de 1958), contrario al mandato constitucional, integró el Consejo, como lo quería un sector de la constituyente, el Ministro de Justicia, con lo cual se mantenía en parte esa relación de dependencia de la judicatura respecto del Ejecutivo que había caracterizado la época anterior. ${ }^{33}$ Pero por otra parte, la ley también cambió el espíritu de la constituyente, pues el sector togado del CSM no estaba representado por todos los jueces, sino que se dio una influencia dominante a los magistrados de casación. Hay que tener presente que parte del espíritu innovador del constituyente de 1947 consistía en igualar el peso entre los distintos grados del orden jurisdiccional. En concreto se intentó restarle poder a la Corte de Casación, que era expresión para un sector importante de la sociedad italiana de ese entonces de conservadurismo y, según otros, de continuidad del fascismo. ${ }^{34}$

Hay que entender la incorporación del CSM a la Constitución italiana en una lógica de mayor autonomía de la magistratura respecto del Poder Ejecutivo, así como de la influencia de la Corte de Casación. Se intentó derribar la vieja jerarquía judicial que se fundaba sobre el control de los concursos y de los escrutinios de parte del núcleo dirigente de la Corte de Casación, lo que según Pizzorusso favorecía de manera inevitable entre los jueces un conformismo respecto de la jurisprudencia conservadora del máximo tribunal. ${ }^{35}$ Por conservadurismo hay que entender en este caso una voluntad de no cambiar las estructuras jurídicas, sociales y económicas que había impuesto años atrás el régimen fascista.

Debe tenerse presente que si bien la creación del CSM en la Constitución de 1947 fue el vehículo institucional para fortalecer y proteger al orden judicial de los condicionamientos ejercidos por el Ministro de Justicia, la abolición de la carrera judicial que comenzó a gestarse en la década de los cuarenta y que terminó de llevarse a cabo en la década de los setenta del siglo pasado, también contribuyó a este radical cambio. El fin de la carrera judicial, a juicio de algunos, fue el instrumento más potente para atacar el conformismo jurisprudencial y la relación que se generaba entre la magistratura y el sistema político. ${ }^{36}$ Desde los

33 Vid. Pizzorusso (1999), p. 103.

${ }^{34}$ Entre 1948 y 1958 la Corte de Casación italiana se destacó por su clara concepción jurídica y política conservadora. En este decenio la suprema corte concentró el poder de control de legitimidad de las leyes, puesto que la Corte Constitucional no entraba aún en funcionamiento, y por otra parte tenía un fuerte poder de control del gobierno de la magistratura. Pero además, con su accionar en el campo propiamente jurisdiccional, la Corte de Casación impidió muchas veces que se realizaran los valores constitucionales libertarios e igualitarios que se quería dejar atrás después de la experiencia fascista. Sobre este aspecto histórico de la Corte de Casación italiana Vid. MENiCONi (2012), pp. 287 y ss.

35 Cfr. Pizzorusso (1990), p. 49.

36 Vid. PEPINO (2009), p. 223. 
años setenta en adelante los jueces italianos se distinguen solo por las funciones desarrolladas, sin que existan jerarquías de tipo orgánicas. Un magistrado de la Corte de Casación no es superior jerárquico ni es superior a un juez de instrucción ni de ningún otro juez o tribunal.

La composición del CSM ha sido modificada por varias leyes en los más de cincuenta años que lleva funcionando. Hoy en día junto al CSM existen los Consejos Judiciales, que asesoran al primero redactando actos respecto de la progresión en la carrera de los magistrados, cambio de funciones y otros hechos referidos a la vida profesional de estos. La relación entre los Consejos Judiciales y el CSM se puede definir como de apoyo y subordinación funcional.

Hay que tener presente que el ordenamiento judicial italiano ha sido objeto de modificaciones los últimos años. Si los primeros cambios después de la Constitución de 1947 apuntaban a reforzar la independencia de los jueces respecto del Poder Ejecutivo y de la Corte de Casación, en el último tiempo se han aprobado leyes que intentan evaluar la capacidad profesional de los jueces, su laboriosidad, diligencia y empeño. Es esto lo que regulan las leyes 160/2006 y la 111/2007.

El CSM trabaja dividido en diferentes comisiones. El Decreto de 31 de julio de 2013 dividió el trabajo en ocho comisiones, suprimiéndose la novena comisión, en atención que la actividad de formación de los jueces se traspasó del CSM a la Scuola Superiore della Magistratura. ${ }^{37}$

De conformidad con lo señalado, en el ordenamiento jurídico italiano los poderes directivos del Ministro de Justicia y de la Corte de Casación han quedado reducidos estos últimos cincuenta años a su mínima expresión. Respecto del Ministro de Justicia, este está legitimado para deducir un requerimiento disciplinario contra los jueces (art. $107 \mathrm{CI}$ ). Además puede efectuar inspecciones en los despachos judiciales, lo que se conecta con su legitimación activa reconocida en materia de responsabilidad disciplinaria de los jueces. También tiene facultades que le permiten anticipar o posponer los traslados de los jueces que ha decidido el CSM. En relación con la Corte de Casación, la legislación prevé la existencia de un Consejo Directivo de la Corte de Casación, que tiene como principal competencia formular observaciones relativas a la valoración de la profesionalidad de los magistrados. Este Consejo Directivo lo componen el Primer Presidente, el Procurador General adscrito a la Corte de Casación y el Presidente del Consejo Nacional Forense, como miembros de pleno derecho. Asimismo, lo componen ocho magistrados vinculados a la Corte, dos profesores universitarios en materias jurídicas, nombrados por el Consejo Universitario Nacional y, finalmente, un abogado con al menos veinte años de ejercicio efectivo de la profesión, nombrado por el Consejo Nacional Forense. Valorando críticamente su rol, Michele

${ }^{37}$ La Scuola Superiore della Magistratura es un órgano autónomo con personalidad jurídica de Derecho Público instituido por el Decreto Legislativo N$^{\circ} 26$ del 30 de enero de 2006. 
Vallefuoco señala que resulta verdaderamente difícil comprender de qué sirve un organismo como este. ${ }^{38}$

Llegados a este punto de la exposición, se hace necesario realizar una síntesis valorativa de cómo ha funcionado el CSM en la sociedad italiana. La terea no es fácil pues el funcionamiento de un órgano de este tipo que tiene por misión fundamental asegurar la independencia y autonomía de la magistratura en su conjunto, supone valorar también cómo funcionan las instituciones políticas y la sociedad italiana en su conjunto.

Si la situación italiana se observa desde Chile, destacan algunos hechos que no están presentes en el caso chileno y con los cuales los jueces chilenos no tienen que lidiar. La presencia de la conocida mafia (o de distintas mafias regionales) que no solo realiza actividades ilegales privadas, sino que involucra muchas veces a lo público y a la política en sus actividades ilícitas, es algo que caracteriza a la sociedad italiana más que a ninguna otra. En segundo lugar, Italia es un país que en el concierto de las economías occidentales desarrolladas es considerado bastante corrupto. ${ }^{39}$ Finalmente, la judicatura italiana ha sido atacada como nunca en los últimos decenios por los gobiernos de turno.

El ataque frontal de las mayorías políticas a los jueces italianos se verifica ya desde los primeros años ochenta del siglo pasado y termina por desencadenar una verdadera crisis institucional en la década de los noventa. La causa se inscribe dentro de lo que termina siendo conocido como Tangentopoli. ${ }^{40}$ Los dirigentes políticos de la mayoría habían sido objeto de intervenciones judiciales. Especialmente conocidas fueron las pesquisas dirigidas por jueces respecto de la dirigencia del Partido Socialista italiano. Luego vinieron las investigaciones contra el Jefe de Estado que determinó que en la década de los noventa el Presidente de la República Francesco Cossiga dirigiera feroces ataques contra jueces y contra el CSM. Luego vinieron serias escaramuzas entre el Primer Ministro Silvio Berlusconi y determinados jueces y el CSM, que duraron hasta hace pocos años. ${ }^{41}$

38 Cfr. Vallefuoco (2013), p. 159.

${ }^{39}$ En el informe sobre corrupción en el mundo del año 2013 de Transparencia Internacional, se ubica a Italia en el puesto $\mathrm{N}^{\circ}$ 69. Chile figura en el puesto $\mathrm{N}^{\circ} 22$ y es el segundo país menos corrupto de Latinoamérica después de Uruguay.

${ }^{40}$ Se conoce con este nombre a la situación de cambio político que se dio en Italia a causa de la investigación judicial realizada por los jueces requirentes (fiscales del Ministerio Público, que en Italia son jueces), organizados desde Milán bajo el procurador general Francesco Severio Borrelli. Dicha investigación judicial tuvo por objeto conocer y sancionar los mecanismos ilícitos de financiamiento de la política en conexión con grandes intereses económicos obtenidos por concesiones de obras públicas y legislaciones sectoriales particularmente ventajosas para políticos y empresarios vinculados a los primeros.

${ }^{41}$ El conflicto institucional trajo como resultado una modificación importante sobre la situación y estatus de los jueces italianos. Se modificó el sistema de carrera judicial, la que dejó de ser por ancianidad para tener importancia la profesionalidad y capacidad de los jueces medidos por 
De conformidad con lo señalado precedentemente, la valoración del funcionamiento del CSM para garantizar la independencia de la magistratura debe ser realizada teniendo como base un conflicto institucional especialmente grave en el contexto de un Estado de Derecho que consagra la clásica división de poderes, como es el caso de Italia.

Si uno analiza la doctrina italiana que ha estudiado al órgano de administración de la judicatura, se puede constatar una cierta satisfacción con su funcionamiento. En algunos casos se habla de un modelo -el "modelo italiano" -, que destaca por su originalidad y por mostrar niveles comparativamente muy elevados de independencia institucional. ${ }^{42}$ Existen desde luego algunas voces críticas, pero no se ha podido encontrar ninguna posición que pretenda quitarle la administración de la magistratura al Consejo y fortalecer al contrario al Ministro de Justicia o a la Corte de Casación.

Algunas opiniones críticas apuntan hacia una cierta politización del órgano o de su actuar. Rebuffa plantea que la introducción del CSM significó quitarle al Ejecutivo su interferencia sobre la magistratura. Pero significó a su juicio un nuevo riesgo, al menos teórico, de una nueva subordinación de la magistratura ahora a los partidos políticos, ni mejor ni peor que lo que había antes, simplemente, señala, distinta. ${ }^{43}$ Ferrara, contrariando la posición de Rebuffa, sostiene que hoy en día el rol que juega el CSM como instrumento de garantía de mayor autonomía e independencia de los jueces no se determina desde los "lugares del poder", sino fundamentalmente desde los propios jueces y del CSM. Y en este sentido destaca que al interior del órgano, más que diversas corrientes políticas, existen diversas representaciones culturales. A su juicio, la existencia de estas diversas expresiones culturales al interior del CSM constituye algo positivo para los jueces y especialmente para los ciudadanos y es algo muy distinto del juego de representación política. No corresponde a su juicio hablar de politización del Consejo. ${ }^{44}$

Los comentarios de Ferrara tienen como premisa la situación de control del CSM por parte de las corrientes asociativas de los jueces, fenómeno que se verifica desde la década de los setenta del siglo pasado. Esas corrientes eran expresión de las afinidades políticas de los jueces y como tal se habla desde esta época de una magistratura más politizada. ${ }^{45}$ Pero autores como Ferrara rechazan por simplista esta tesis de la politización del CSM. A su juicio, las fuerzas al

exámenes y concursos. Todo ello habría supuesto, a decir de algunos, una maniobra política de la mayoría conservadora de ese entonces contra el trabajo de los jueces considerado por ese sector político abusivo y politizado. Vid. BARTOLE (2008), p. 84. Para un análisis más completo sobre el conflicto judicatura-política en Italia remito al trabajo de MENICONI (2012), p. 344 y ss.

42 Vid. Pederzoli (2004), p. 70.

43 Cfr. ReBUfFA (1993), p. 92.

44 Cfr. Ferrara (2001), p. 245.

45 Vid. Pagliuca (2013), p. 208. 
interior del CSM, ya sea aisladamente o bien bajo las asociaciones de magistrados, más que expresión de un poder de representación política de determinados intereses o necesidades, son expresión de la diversidad de valores y de identidades culturales que existen en la sociedad italiana. ${ }^{46}$

Dejando de lado el análisis sobre una supuesta politización del CSM, las críticas más recurrentes apuntan hacia una deficiencia en el funcionamiento del órgano y hacia una cierta laxitud en el sistema disciplinario.

Desde el punto de vista de la eficiencia en el actuar del CSM, Pizzorusso destaca que su funcionamiento ha sido seriamente obstaculizado por el hecho de tener que actuar en colaboración con órganos que funcionan con una lógica y principios diferentes, como ocurre con los Consejos Judiciales. Esto ha llevado a que el CSM ha debido asumir una enorme carga de funciones que podrían haber sido desarrolladas por estos órganos auxiliares descentralizadamente. Por otra parte, se presenta el problema del control vía jurisdicción contenciosa administrativa de los actos administrativos del CSM. Ocurre así que cuando el CSM hace un nombramiento se interpone una reclamación ante el tribunal administrativo competente, suspendiéndose cautelarmente el acto muchas veces sin la más mínima fundamentación. Ello hace que nombramientos que eran urgentes queden suspendidos y obstaculizados por la burocracia y lentitud propia de la justicia. En este sentido, se dice que los "jueces administrativos prestan demasiada atención a los intereses de los recurrentes y demasiado poca al interés general del país". ${ }^{47}$

Desde el punto de vista del rol que cumple el CSM como órgano de corrección de la disciplina de los jueces italianos, Rebuffa denuncia un conformismo y laxitud en su funcionamiento. Señala al respecto que frente a los retardos injustificados en el trabajo de los jueces, el CSM no ha sancionado esas conductas disciplinariamente. Habría a su juicio una actitud política-sindical del órgano de administración de la judicatura que ha generado un amplio sistema de inmunidad para los jueces italianos. ${ }^{48}$ Livio Pepino no está de acuerdo con esta apreciación. A su juicio las estadísticas del CSM demuestran que no existe tal laxitud ni inmunidad. Comentarios como los de Rebuffa esconderían en concepto de Pepino un interés en utilizar la responsabilidad disciplinaria como un instrumento que permitiría dirigir ideológicamente el trabajo de los jueces, construyendo por esta vía un determinado modelo de juez. ${ }^{49}$

Termino esta parte con la sugerencia que propone Ferrara. Antes de introducir modificaciones sustanciales al CSM, habría que reflexionar si no

\footnotetext{
${ }^{46}$ Cfr. Ferrara (2001), p. 245.

${ }^{47}$ PizZORUSSO (1999), p. 106.

48 Vid. ReBUfFA (1993), p. 109.

${ }^{49}$ Cfr. PePINO (2009), p. 231. Se debe comentar que Giorgio Rebuffa terminó participando activamente en política en Forza Italia, el partido político dirigido por Silvio Berlusconi.
} 
obstante las disfunciones y defectos que pueden observarse en la vida del CSM, este ha desarrollado o no un rol determinante para la tutela de la autonomía y de la independencia de la magistratura en Italia. ${ }^{50} \mathrm{El}$ autor deja abierta la respuesta. Sin embargo, se puede intentar una respuesta como observador externo. En un país como Italia que vive profundamente en una cultura de la ilegalidad y del abuso, tanto en el mundo privado como en el político, el que los jueces puedan trabajar diariamente aplicando la ley, supone una organización administrativa de la judicatura que les permite a los jueces cumplir el mandato constitucional que ordena que los jueces están sometidos a la ley y solo a la ley. El CSM pareciera ayudar a que el mandato constitucional se cumpla.

\section{E1 Consejo General del Poder Judicial}

La Constitución italiana de 1947 es un importante referente para la Constitución española de 1978. Son varias las instituciones constitucionales españolas que tienen origen en el derecho público italiano. Y en materia de organización judicial "está fuera de toda duda que el constituyente español de 1978 se inspiró en la Constitución italiana al proyectar el Consejo General de Poder Judicial [en adelante CGPJ], claramente, como alternativa al sistema de gobierno desde el ejecutivo". ${ }^{51}$

Además de quitarle injerencia al Ejecutivo sobre los tribunales de justicia, la introducción del CGPJ en el sistema constitucional español intentó desactivar el componente jerárquico, representado por el poder que ejercía el Tribunal Supremo que, entre otros aspectos, le correspondía el control disciplinario intrajurisdiccional de los tribunales.

Sobre la naturaleza del CGPJ, la doctrina española sigue de cerca la discusión que analizamos respecto del Consejo italiano. En efecto, se señala que es un órgano que carece de potestad jurisdiccional y es la cúspide administrativa del Poder Judicial. En la cúspide jurisdiccional del Poder Judicial se encuentra el Tribunal Supremo, aunque esa doble cúspide -administrativa y jurisdiccional- encuentra unión en la figura del Presidente del Tribunal Supremo, pues a la vez lo es del CGPJ.

Víctor Moreno señala que no es correcto señalar que el Consejo cumpla solo una función administrativa o de gestión burocrática, sino que se trata de un órgano que tiene potestades de política judicial con grandes espacios para adoptar decisiones discrecionales, como sucede con los nombramientos y ascensos de los jueces. ${ }^{52}$ No creo que de las palabras de este último autor se deba entender que

\footnotetext{
${ }^{50}$ Cfr. Ferrara (2001), p. 249.

51 ANDRÉs (1999), p. 27. Otros autores no refieren el punto al modelo italiano, sino que lo proyectan a un plano más general del derecho constitucional europeo de la posguerra. Vid. BLANCO (2004), p. 164. Pascual Sala visualiza tal inspiración en los modelos italiano y francés. Cfr. SALA (2003), p. 233.

52 Cfr. MORENO (2005), p. 274.
} 
estamos frente a un órgano político que gestiona intereses generales. Existe cierto consenso en la mayoría de la doctrina que estamos frente a un órgano administrativo. De hecho corresponde a la sala de lo contencioso administrativo del Tribunal Supremo el conocimiento de los recursos contencioso administrativos interpuestos contra los actos del Consejo (arts. 58.1 LOPJ y 12.1 b) LJCA). Hay que agregar que muchos órganos administrativos también tienen facultades discrecionales y eso no los hace necesariamente órganos de dirección política.

El CGPJ no es un órgano de autogobierno de la judicatura, pues lo componen miembros que no son jueces y además se encuentra plenamente sometido al control jurisdiccional. Por otra parte, tampoco se puede decir que es el único ente que gobierna o administra a la judicatura. Existen varios aspectos de su funcionamiento que hasta el día de hoy controla el Ejecutivo, como la convocatoria a plazas y el presupuesto para los juzgados y tribunales. ${ }^{53}$ Jaime Vegas señala que ni siquiera se puede hablar de órgano de gobierno de la judicatura con el CGPJ, pues solo es el órgano de garantía de la independencia judicial. Su tesis se basa es que son muy pocas las competencias que tiene en materia de gobierno o administración judicial, ya que solo le corresponde la gestión del personal referido exclusivamente a jueces y magistrados. Todo lo demás relativo a la administración judicial, como la gestión de medios materiales o la gestión del personal no judicial, es resorte del poder ejecutivo, estatal o autonómico. $^{54}$

Pero si al CGPJ le corresponde el nombramiento, el ascenso y el control de la disciplina de los jueces y magistrados, que son los que con exclusividad ejercen jurisdicción, entonces hay que entender que el gobierno o la administración de la judicatura le corresponde en la parte más trascendental a este órgano.

El CGPJ en su previsión constitucional (art. 122.3) se compone de veinte vocales, además del Presidente del Tribunal Supremo que lo preside. De los veinte vocales doce son elegidos entre jueces y magistrados de todas las categorías judiciales y ocho son elegidos por las Cortes Generales; cuatro por cada Cámara, entre abogados y juristas de reconocida competencia con más de quince años de ejercicio profesional.

El CGPJ se compone de tres Comisiones reguladas en la Ley Orgánica del Poder Judicial (LOPJ); Comisión permanente, disciplinaria y de calificación. Autónomamente el CGPJ ha creado otras comisiones como las de Estudios e informes; Escuela Judicial y presupuestaria.

A diferencia del Consejo italiano, la doctrina tiene una opinión algo negativa sobre el funcionamiento del símil español. Más que problemas de

53 Vid. Belloso (1999), p. 96.

${ }^{54}$ Cfr. Vegas (2012), p. 8. 
ineficiencia o de problemas con la responsabilidad disciplinaria, el tema acá es derechamente de politización del órgano de administración de la judicatura. ${ }^{55}$

En un primer comienzo, en la LOPJ de 1980, si bien bajo la influencia positiva del Consejo italiano se dejó a los propios jueces que eligieran a sus integrantes (los doce que le correspondían), en realidad se previó la elección solo de la oligarquía judicial. ${ }^{56} \mathrm{Y}$ respecto de los ocho restantes que corresponde elegir a las Cortes Generales, fueron designados por la mayoría políticamente gobernante. El resultado fue, según Perfecto Andrés, "un Consejo de partido único, cortado miméticamente por el patrón de esa mayoría e, inevitablemente, muy condicionado por ella, limitado en su capacidad de encarnar un momento institucional de verdadera autonomía y marcado ya por el lastre de un cierto déficit de legitimidad". ${ }^{57}$

De este modo, se puede decir que el CGPJ nació con problemas, sobre todo de legitimidad en su composición. Y en los tiempos que le sucedieron las cosas solo empeoraron. Si el problema era de legitimidad en la composición del órgano, lo que habría que haber realizado es una designación del estamento togado por los propios jueces de todas las categorías. Así se habría espantado el fantasma de la politización y de la judicatura elitista y conservadora que existía, según refiere alguna doctrina, ${ }^{58}$ a fines de los años setenta en España.

El Partido Socialista Obrero Español (PSOE), que conquista el poder en el año 1982, no supo interpretar esta necesidad de cambio y de potenciar la legitimidad del CGPJ. Debido a que en la Constitución española no es clara si la componente togada del Consejo debe estar representada por jueces elegidos por ellos mismos o bien por otro órgano, dicha mayoría política modificó la LOPJ en el año 1985 y procedió a diseñar el sistema de modo que corresponde elegir a todos los jueces que componen el órgano de administración de la judicatura por las Cortes Generales. En definitiva los veinte miembros del CGPJ fueron elegidos por el poder legislativo estatal.

Esta situación generó un grave conflicto institucional, que llevó a la minoría política conservadora a presentar un requerimiento contra la LOPJ ante el Tribunal Constitucional. Este rechazó el recurso ${ }^{59}$ y consideró que la LOPJ diseñada por la mayoría socialista era constitucional. A juicio del tribunal de control de legitimidad constitucional, la Constitución no exige que los consejeros jueces fuesen elegidos por los propios jueces. Pero además expresó que la designación parlamentaria establecida en la ley no significaba necesariamente una

\footnotetext{
55 Vid. ANDRÉS (1999), pp. 27 y 28; FAIRÉN (1999), p. 125; SALA (2003), p. 248.

56 Vid. ANDRÉS (1999), p. 26.

${ }^{57}$ Ibid.

58 Ibid.

${ }^{59}$ Sentencia del Tribunal Constitucional español N 45/1986.
} 
pérdida de autonomía funcional de los consejeros. El Tribunal Constitucional consideró que si bien el pluralismo existente en la sociedad española y en el seno del Poder Judicial se alcanzaba de mejor modo si la composición togada del Consejo proviniera de los propios jueces antes que de una designación parlamentaria, aplicó la doctrina del selfrestraint y determinó que los problemas que pudieran derivarse de una designación completamente parlamentaria no eran motivo suficiente para declarar la invalidez de un precepto legal, pues este permitía una interpretación conforme con la Constitución. ${ }^{60}$

El tema de la elección de los consejeros del CGPJ ha comportado un disenso político entre las dos grandes mayorías políticas del país, ${ }^{61}$ es decir, el PSOE y el Partido Popular (PP), mayorías de centroizquierda y centroderecha, respectivamente. Ese disenso ha intentado caminos de solución con dos reformas importantes al órgano: la del año 2001 y la reciente de 2013.

Mediante la Ley $\mathrm{N}^{\circ} 2$ de 28 de junio de 2001 se dispuso que los miembros togados del CGPJ fuesen elegibles entre jueces y magistrados de todas las categorías judiciales por las Cortes Generales, pero con una proposición previa de las asociaciones profesionales de jueces y magistrados o de un número de jueces que representaran al menos el $2 \%$ de todos aquellos que se encuentren activos.

La reforma del 2001 parece no fue lo exitosa que se esperaba. Desde luego con este nuevo diseño los más perjudicados fueron los jueces no asociados. ${ }^{62}$ Pero además hay quien sostiene que la elección de los consejeros togados con participación de las asociaciones de magistrados no es garantía de despolitización del órgano. En España, según algunos autores, ${ }^{63}$ la separación de las asociaciones judiciales responde a las mismas divergencias que las que se manifiestan en el ámbito de la representación política y parlamentaria. Si ello es así, "no se comprende la afirmación de que la elección parlamentaria contamina políticamente y, sin embargo, no lo hace la corporativa". ${ }^{64}$

Como se puede observar, la doctrina española es muy crítica con el funcionamiento del CGPJ. El sistema de designación ha sido generalmente lo más criticado. Se acusa al sistema de discrecional y politizado. El nombramiento discrecional es especialmente relevante tratándose de Presidencias de Audiencias, Tribunales y Salas, o respecto de magistrados del Tribunal Supremo. Estas nominaciones corresponden a un verdadero reparto de cargos entre los bloques o sensibilidades políticas que operarían al interior del CGPJ. ${ }^{65}$

\footnotetext{
${ }^{60}$ Vid. BLANCO (2004), p. 168.

${ }^{61}$ Ibid., p. 169.

62 Vid. RuIZ-RiCO (2004), p. 195.

${ }^{63}$ Vid. SALA (2003), p. 246.

64 Ibíd. Véase también últimamente LUCAS (2012), p. 4.

65 Vid. VEGAS (2012), p. 11.
} 
Pero más allá de este aspecto, un sector de la doctrina pone acento en su funcionamiento, que tendría un elevado número de consejeros con una dedicación desproporcionada respecto de las funciones razonablemente justificadas. A ello se agrega el tema de una proliferación competencial no siempre provechosa. ${ }^{66}$

Toda esta crítica ha sido escuchada por la coalición de gobierno que dirige el país desde el año 2011 -el Partido Popular-, la que presentó una modificación a la LOPJ, siendo aprobada con fecha 28 de junio de 2013 . Lo que hizo esta reforma legal fue quitarles peso a las asociaciones de magistrados en la designación de los vocales. Por otra parte, intentó una representación mayoritaria de jueces en el seno del órgano.

Con la nueva ley, los vocales de procedencia judicial (12) pueden estar representados por cualquier juez o magistrado, pero la ley les exige un aval de veinticinco jueces en servicio activo o bien de una asociación judicial legalmente constituida. Cada uno de los jueces o magistrados o asociaciones judiciales podrá avalar hasta un máximo de doce candidatos. Se establece además que entre las doce vacantes judiciales debe haber un mínimo de tres magistrados del Tribunal Supremo, tres magistrados con más de veinticinco años de antigüedad en la carrera judicial y seis magistrados o jueces sin sujeción de antigüedad. Si no existieran candidatos a vocales dentro de alguna de las mencionadas categorías, la vacante acrecerá el cupo de la siguiente por el orden establecido en la ley.

Respecto de los vocales de origen parlamentario (8), la ley de 2013 se abre a la posibilidad de que estos sean jueces o magistrados que no se encuentren en servicio activo en la carrera judicial y que cuenten con más de quince años de experiencia profesional, teniendo en cuenta para ello tanto la antigüedad en la carrera judicial como los años de experiencia en otras profesiones jurídicas. Sin embargo, para Agustín Pérez-Cruz "dicha posibilidad supone una abierta contravención a la composición mixta prevista en el art. 127.3 C.E., pues pudiera darse la hipótesis de que todos los vocales fueran miembros de la Carrera Judicial". ${ }^{67}$

Llegados a este punto, hay que señalar que sin perjuicio de la crítica que se le hace al órgano de administración del poder judicial, no parece existir en la doctrina jurídica española el deseo de que las cuestiones atinentes a la administración de la judicatura, como nominaciones, ascensos, traslados, sanciones, sean competencia del Ejecutivo a través del Ministro de Justicia o del Tribunal Supremo. Así, un fuerte crítico del actuar del Consejo los últimos años, como Jaime Vegas, sostenía el año 2012 en la antesala a la reforma llevada a cabo el 2013, que por supuesto no cabía eliminar la competencia del CGPJ en materia

66 Vid. Ollero (2012), p. 8.

${ }^{67}$ Pérez-Cruz (2013), p. 217. 
de nombramientos de jueces y magistrados, pues aparte de que la Constitución no le permite, el remedio sería peor que la enfermedad.

En materia de nombramientos judiciales, Vegas propone reducir los cargos de designación discrecional y potenciar la promoción de la carrera judicial mediante los principios de mérito y capacidad. ${ }^{68}$ En este mismo sentido, Pablos Lucas Murillo de la Cueva coincide en la necesidad de intensificar los elementos reglados de los nombramientos llamados discrecionales. ${ }^{69}$ Ninguno de estos autores propone la eliminación del órgano.

Si el gran problema del CGPJ ha sido históricamente su politización, la reforma legal de 2013 debería mejorar este aspecto favoreciendo el marco institucional para la independencia judicial. Pero como en todo orden de cosas, todo dependerá en definitiva del factor ético-cultural imperante en los jueces y si la independencia judicial como valor constitucional sea considerada relevante por el mundo político. ${ }^{70}$ En relación con este último punto, también se propone por un sector de la doctrina poner atención no tanto en los mecanismos de selección de los vocales del Consejo, sino en quiénes son elegidos. Es así que Pablo Lucas Murillo de La Cueva pone acento en la competencia acreditada de quienes vayan a ser propuestos, más allá de la sola condición de juez o magistrado en un caso, y el prestigio profesional en el caso de los juristas designados por el Parlamento. El sistema -agrega- debería excluir a los que no tienen preparación, los identificables como parciales o sectarios, y los que tienen dependencia partidista o asociativa. ${ }^{71}$

Finalmente, no se debe omitir que España tiene niveles de corrupción bastante superiores a los de Chile. ${ }^{72}$ No tiene problemas como los de la mafia en Italia, pero la implicación de políticos en negocios y actos ilícitos es bastante mayor de lo que existe en Chile. Son muchos los casos que reporta la prensa española de jueces que persiguen y condenan a políticos españoles por actos de corrupción. Debido a ello controlar en algún sentido al órgano de gobierno del poder judicial es algo que tiene interés para los políticos españoles. Esta situación no se da con la misma intensidad en Chile y ello hay que tenerlo presente en una evaluación del sistema de gobierno y administración de la judicatura.

\section{E1 Consejo Superior de la Judicatura}

El Consejo Superior de la Judicatura (CSJ) fue introducido originalmente en el derecho colombiano en el año 1955, el que luego pasó a transformarse en el año

\footnotetext{
68 Vid. VEGAS (2012), p. 11.

${ }^{69}$ Cfr. LuCAS (2012), p. 1.

70 Vid. ANDRÉS (2012), p. 61.

${ }^{71}$ Cfr. LUCAS (2012), p. 6.

72 En el informe sobre corrupción en el mundo del año 2013 de Transparencia Internacional se ubica a España en el puesto $\mathrm{N}^{\circ} 40$. Recordemos que Chile figura en el puesto $\mathrm{N}^{\circ} 22$.
} 
1972 en Tribunal Disciplinario. Luego volvió a constituirse como Consejo Superior de la Judicatura en el año 1979 mediante reforma constitucional, la que fue declarada inconstitucional por la Corte Suprema en el año 1981. Con fecha posterior, en 1991, fue incorporado definitivamente en el nuevo texto constitucional colombiano. El órgano permanece hasta estos días.

Las justificaciones para la creación de este órgano en la Constitución de 1991 fueron varias. Se buscaba en primer término potenciar la independencia de los jueces, pero también buscaba modernizar todas las instituciones de apoyo al sistema judicial, así como descentralizar en algunos aspectos las competencias en materia de administración judicial. ${ }^{73}$

Antes de crearse el CSJ los funcionarios judiciales consideraban que no tenían autonomía por la dependencia que existía respecto del Ministerio de Justicia. Además de falta de independencia, había una crítica al trabajo judicial realizado con bastante precariedad de medios. De este modo, la opinión que existía antes de la creación del órgano es que si se garantizaran autonomía judicial, carrera administrativa y mejores sueldos, mejoraría sustancialmente la administración de justicia, en términos de oportunidad en la dictación de los fallos y de menor corrupción o impunidad. $^{74}$

Para lograr estos objetivos de mayor independencia y mejor gestión en la administración de justicia y fallos mejores y más rápidos, se crearon dos salas al interior del CSJ: la Administrativa y la disciplinaria.

A los miembros de ambas salas se les denomina magistrados. Sin embargo, existen dudas si los miembros de la sala son magistrados. Existe opinión de que no son magistrados sino funcionarios que cumplen tareas propias de los administradores públicos. ${ }^{75}$

Respecto de los miembros de la sala disciplinaria la situación es más discutida, pues entre sus competencias está la de resolver conflictos de relevancia jurídica. Para María Mercedes López Mora, integrante de la sala disciplinaria del CSJ, es meridianamente claro que los magistrados de la sala disciplinaria son jueces. La sala disciplinaria controla la conducta ministerial no solo de los jueces sino también de los abogados. Para López, en virtud del principio de independencia judicial, es evidente que un juez solo puede ser enjuiciado por otro juez. "El poder judicial no puede ser intervenido judicialmente sino por el mismo

\footnotetext{
73 Vid. Olano (2004), p. 294.

74 Vid. GaLVIS (2012), p. 165.

75 Vid. GaLVIS (2012), p. 169.
} 
poder judicial y no por ninguna de las otras ramas que conforman la tripartición del poder público del Estado". ${ }^{76}$

Para Javier Henao las decisiones disciplinarias del CSJ no son actos jurisdiccionales, sino administrativos, pues de ellos se puede reclamar ante la jurisdicción de lo contencioso-administrativo, que es la instancia ordinaria de control de los actos administrativos en Colombia. ${ }^{77}$

El CSJ se compone, por decisión constitucional, de trece miembros (siete en la sala jurisdiccional y seis en la administrativa). Los miembros de la sala administrativa son elegidos de la siguiente manera: dos por la Corte Suprema de Justicia; uno por la Corte Constitucional y tres por el Consejo de Estado. Los de la sala jurisdiccional disciplinaria son elegidos por el Congreso Nacional en virtud de ternas previas elaboradas por el Gobierno. Por otra parte, el órgano opera descentralizadamente por medio de Consejos Seccionales de la judicatura en las ciudades cabecera de distrito judicial.

Atendiendo a la clasificación que propone el autor Israel Rivas en orden a la autonomía, rol y competencias que tienen los Consejos de la Judicatura, entre activos, híbridos y pasivos, el CSJ es considerado por él como activo, pues tiene amplias facultades incluidas las de diseño de políticas judiciales. ${ }^{78}$

El balance del funcionamiento del CSJ es bastante negativo. Las críticas que se le suelen hacer apuntan hacia una cierta politización en la sala disciplinaria y bastante ineficiencia en la administrativa.

Respecto de la politización en la designación de los miembros de la sala disciplinaria, el problema se refiere a quienes han sido elegidos para los cargos. Se expresa que ellos son "políticos profesionales", 79 o bien amigos o recomendados del Presidente de turno. Además se señala que para ser nombrado se tiene que hacer antesala con los políticos en el Congreso Nacional para esperar sus favores. En la nominación se privilegia muchas veces el origen regional o político. ${ }^{80} \mathrm{En}$ la mayoría de las nominaciones al CSJ, se señala que no llegan personas con mérito y con la capacidad requerida. ${ }^{81}$

Uno de los aspectos centrales en la creación del CSJ era el de modernizar el sistema judicial y hacer más eficiente el ejercicio de la función jurisdiccional. Como

\footnotetext{
${ }^{76}$ Entrevista realizada a la magistrada María Mercedes López Mora integrante de la sala disciplinaria del CSJ, en Bogotá, el 1 de junio de 2012.

77 Vid. Henao (2004), p. 295.

${ }^{78}$ Vid. RIVAS (2011), p. 61.

${ }^{79}$ Opinión de la magistrada del CSJ María Mercedes López Mora

80 Vid. Galvis (2012), p. 168.

${ }^{81}$ Ibid.; López Mora, María Mercedes, en la entrevista referida.
} 
dato relevante Javier Henao destaca el hecho de que luego de la introducción del CSJ en el año 1991, el número de funcionarios judiciales que se crearon entre 1991 y 1994 fue de 14.184 (se pasó de 26.252 en 1991 a 40.536 en 1994). Pero todo este esfuerzo para el país, sobre todo económico, no se refleja en una "mejor calidad de la administración de justicia y tampoco en la disminución de los índices de impunidad y de congestión (atraso judicial)". ${ }^{82}$

Frente a este panorama tan crítico sobre el funcionamiento del CSJ, un sector importante de la doctrina colombiana aboga por la supresión del órgano. ${ }^{83}$

Para concluir sobre la valoración crítica del CSJ, es necesario tener presente que Colombia figura entre los países más corruptos a nivel latinoamericano, ${ }^{84}$ por lo que hay que considerar que cualquiera sea el sistema de gobierno de la judicatura, no se puede descartar una gestión que considere los intereses políticos y económicos en juego y una mancomunión entre los que designan o promueven a los jueces y estos últimos. No hay antecedentes que permitan afirmar que en Colombia, un gobierno de la judicatura en manos del Ejecutivo o del Tribunal Supremo, lo haría de mejor modo que el CSJ.

\section{Propuesta para el derecho chileno}

De conformidad con el análisis sobre el gobierno judicial vigente en Chile así como las experiencias comparadas sobre los Consejos de la Judicatura, postulo que nuestro país debería caminar hacia una gestión judicial a cargo de un Consejo de la Judicatura similar al modelo italiano, ${ }^{85}$ que es uno de los que funcionan mejor en el derecho comparado. Le llamaré a ese órgano que se propone introducir Consejo Nacional de la Jurisdicción. ${ }^{86}$

Es esencial una regulación adecuada de este órgano, la que debe evitar dar una preponderancia a la designación de los poderes políticos de sus miembros y,

\footnotetext{
${ }^{82}$ HeNAO (2004), pp. 299 y 300

83 Vid. OLANO (2004),p. 328; GALVIS (2012), p. 172.

${ }^{84}$ En el informe sobre corrupción en el mundo del año 2013 de Transparencia Internacional se ubica a Colombia en el puesto $\mathrm{N}^{\circ}$ 94. Recordemos que Chile figura en el puesto $\mathrm{N}^{\circ} 22$.

85 Una valoración positiva del CSM tiene también en nuestro país María Inés Horvitz. Vid. HORVITZ (2007), p. 137.

86 El nombre Consejo Nacional de la Jurisdicción obedece a que lo que debe regular la Constitución no es al Poder Judicial, entidad de tipo administrativa que no es sinónima de los órganos que ejercen la función jurisdiccional. Lo que debe regular la Constitución en su parte orgánica son los tribunales de justicia, pues ellos son los que ejercen la función jurisdiccional. Se puede hablar entonces de tribunales de justicia, judicatura o jurisdicción en su dimensión orgánica; función jurisdiccional en su dimensión procesal. Y el órgano que administra a estos órganos podríamos llamarlo como Consejo Nacional de los tribunales de justicia o de la judicatura o de la jurisdicción. Por economía de lenguaje propongo usar Consejo Nacional de la Jurisdicción. Podría ser también de la Judicatura, aunque esta expresión tiene menos raigambre en nuestro derecho.
} 
de otra parte, se debe evitar una composición proveniente exclusivamente del mundo judicial, pues ello favorecería el corporativismo y la lejanía de la administración judicial de la ciudadanía.

El Consejo Nacional de la Jurisdicción que propongo debería tener una composición mixta, es decir, de jueces elegidos entre sus pares sin diferenciación por tipo de tribunal (un juez un voto) y de abogados designados por el Presidente de la República y el Congreso Nacional. Una idea a discutir consiste en un órgano compuesto por doce miembros, siete de los cuales serían jueces elegidos por sus pares. El Presidente de la República elegiría a un miembro quien actuaría como Presidente del Consejo. El Senado elegiría a dos y los otros dos la Cámara de Diputados.

Para evitar la politización excesiva o indebida del órgano y para evitar su uso como caja pagadora o de compensación para sujetos que hayan perdido elecciones políticas o para evitar el traslado desde cargos políticos al Consejo, se hace aconsejable establecer como inhabilidad para ser designado en el cargo el hecho de haber desempeñado cargos de elección popular así como haber sido candidatos a dichos cargos. Se puede discutir si establecer un plazo o no a dicha inhabilidad. Del mismo modo estarían inhabilitadas aquellas personas que hayan desempeñado funciones en el Gobierno o Administración del Estado en cargos que sean de exclusiva confianza del Presidente de la República en los últimos ocho años. De este modo se asegura de mejor manera no la imparcialidad del órgano, que al no desarrollar funciones jurisdiccionales no la necesita (salvo en la parte disciplinaria), pero sí alejar toda sombra o sospecha por parte de la ciudadanía que los miembros del Consejo desarrollarán sus funciones con fines políticos o de favorecimiento a su partido o sector político.

Ahora bien, no hay que caer en la ilusión de una despolitización absoluta en la designación de los integrantes del Consejo ni en la actuación de este, pues un cierto componente político en la gestión de los asuntos públicos siempre existirá. Lo que se quiere evitar en un uso político abusivo del órgano, donde políticos bajo las órdenes de sus partidos o sectores políticos en el gobierno o el Congreso Nacional tomen las decisiones trascendentales referidas a la judicatura.

Los jueces elegidos en el Consejo quedarían suspendidos en el cargo de juez mientras dure su mandato, operando alguna figura administrativa del tipo permiso o excedencia por todo su período.

Por otra parte, para evitar que el estamento togado tome sus decisiones con una lógica corporativa y en consideración a que son mayoría en el órgano, los acuerdos del Consejo deberán adoptarse con un alto quórum, como podría ser de dos tercios o de tres cuartas partes de los miembros en ejercicio. Así se obligaría a los jueces integrantes del Consejo a adoptar sus acuerdos deliberando y negociando sus puntos de vista con el estamento no togado. 
Cabe agregar que este Consejo Nacional de Jurisdicción para que pueda funcionar adecuadamente necesita de una adecuada plasmación constitucional. Se necesita para todo ello de reformas al Capítulo Sexto de la Constitución. Esta reforma introduciría al Consejo Nacional de la Jurisdicción como órgano de gobierno o administración de la judicatura y haría de la Corte Suprema exclusivamente un tribunal de justicia; la corte de casación, nulidad y revisión.

Las competencias de este órgano dicen relación con el nombramiento de los jueces, su calificación, capacitación, traslado, destitución y demás medidas disciplinarias. Por otra parte debe tener a su cargo toda la gestión de los medios físicos y financieros para el adecuado funcionamiento de la función jurisdiccional. El Consejo Nacional de la Jurisdicción debería apoyarse en otros órganos administrativos que ya existen, como lo son la Corporación Administrativa del Poder Judicial y la Academia Judicial. Posiblemente el primer órgano requiera de mayores ajustes, pero la estructura y experiencia de ambos órganos es algo que debe aprovecharse en esta futura reforma del gobierno judicial chileno.

Por último, es esencial poner de relieve que en los aspectos de dirección y gestión judicial, ya sea en el Consejo o en los órganos colaboradores, los responsables deben ser personas expertas en gestión. Esta exigencia debería excluir en principio a abogados para el ejercicio de estas tareas. Lo anterior quiere decir que si bien el Consejo debe estar integrado por jueces y abogados, pueden crearse secciones o cargos de gestión en su seno o en los órganos auxiliares que deben ser ocupados por personas con conocimientos en gestión, como administradores públicos, ingenieros comerciales o ingenieros civiles, entre otras profesiones.

\section{Conclusiones}

De conformidad con lo que se ha analizado precedentemente, parece ser que no hay sistema de gobierno o administración de la judicatura que sea perfecto. La independencia de la judicatura es un valor esencial en todo estado de derecho, pero como principio constitucional es un ideal a perseguir que se conquista solo parcialmente. Siempre existen interferencias sobre la nominación, promoción o sanción de los jueces. A veces esas interferencias provienen desde el mundo político y en otras ocasiones desde los superiores jerárquicos de los jueces. Y en ocasiones los intereses de la clase política dominante coinciden con los de la dirigencia de los tribunales superiores, por lo que la interferencia se potencia y se cruza.

En Chile tenemos problemas tanto desde el punto de vista de la independencia interna como de la externa. Además de ello existe mucho espacio para la discrecionalidad, lo que favorece el sometimiento político y relaciones personales que van en contra del principio de independencia que es a su vez instrumento de la imparcialidad judicial. El sistema podría mejorar mucho si la nominación, carrera y sanción de los jueces se realizara mediante procedimientos absolutamente reglados, como podrían ser pruebas objetivas, tratándose de 
nominación o carrera de los jueces, o bien con conductas completamente tipificadas en el caso de las sanciones disciplinarias. Pero si el sistema caminara hacia una objetivación o reglamentación de los aspectos más importantes de la organización judicial (nominación, carrera y control disciplinario), surge la pregunta de por qué encomendar esas labores a los tribunales de justicia, como lo son la Corte Suprema y las Cortes de Apelaciones.

La labor de gobierno judicial que se describe se asemeja mucho más a una tarea administrativa y es mejor que un órgano de esa naturaleza realice tales tareas. Esa es la tendencia mundial en los países occidentales que han instaurado el sistema de Consejo de la Judicatura. En general todos los países de nuestro entorno rechazan que tanto un tribunal de justicia o el Ministro de Justicia dirijan o administren la judicatura.

La experiencia de los países que han introducido Consejos de la Judicatura que analizamos en estas páginas es disímil. De bastante positiva en el caso de Italia, bastante cuestionada en España a abiertamente rechazada en Colombia. Pero como se ha hecho ver en estas páginas, se trata de países que presentan características políticas y culturales diferentes a Chile, pues muestran niveles de corrupción y de enfrentamiento entre el mundo político y judicatura especialmente agudos. En este sentido, toda comparación debe tener presente este sustrato sociocultural imperante. Así, se podría proyectar que cualquiera sea el sistema de gobierno de la judicatura que tuviesen los países analizados, en definitiva se producirán serios problemas referidos a actuaciones fuera de la ley o contrarias a las buenas prácticas o a la ética.

De conformidad con este análisis, Chile debería caminar hacia una gestión judicial a cargo de un Consejo de la Judicatura similar al modelo italiano, que parece ser es uno de los que funciona mejor en el derecho comparado. Le llamaré a ese órgano que se propone introducir Consejo Nacional de la Jurisdicción. La introducción de este órgano supone modificar en varios aspectos el capítulo VI de nuestra Constitución.

Para terminar, cualquiera sea el sistema de gobierno o administración judicial que se adopte, para su total éxito se requiere fortalecer los elementos reglados en los actos administrativos de gestión, reduciendo ostensiblemente los actos discrecionales. En Chile tenemos una gran tarea pendiente en este aspecto. 
Bordalí - Propuestas para un nuevo gobierno judicial en Chile

\section{BIBLIOGRAFÍA}

* ANDrÉs Ibáñez, Perfecto (1999): "Poder judicial y juez en el Estado constitucional de derecho. El sistema del Consejo", en AA.VV, La experiencia jurisdiccional: Del Estado legislativo de derecho al Estado constitucional de derecho (Madrid, Escuela Judicial, Consejo General del Poder Judicial).

* (2007): "Poder judicial y juez en el Estado Constitucional de derecho. El sistema de consejo", en En torno a la jurisdicción (Buenos Aires, Ediciones del Puerto).

* _ (2012): “La independencia judicial y los derechos del juez", en Saiz, Alejandro (director), Los derechos fundamentales de los jueces (Madrid, Marcial Pons).

* Balboni, Enzo (2006): "Potere politico e funzione giurisdizionale: Il fondamento costituzionale", en Manna, Adelmo y Lorusso, Sergio (edits.), La reforma dell'ordinamento giudiziario train di pendenza della magistratura e primato della politica (Milán, Giuffrè).

* Bartole, Sergio (2008): Il potere giudiziario (Bolonia, Il Mulino).

* Belloso, Nuria (1999): El control democrático del Poder Judicial en España (Curitiba, Moinho do verbo editora).

* Blanco Valdés, Roberto (2004): "I giudici: "Boca della legge" o potere dello Stato. Una riflessione in torno alla posizione costituzionale del potereg iudiziario in Spagna", en Gambino, Silvio (editor): La Magistratura nello Stato costituzionale. Teoria edesperienze a confronto (Milán, Giuffrè).

* Bonifacio, Franco y GiacobBe, Giovanni (1986): La magistratura.Tomo II. art. 104 - 107 (Bolonia, Zanichelli).

* Bordalí, Andrés (2013): "La independencia de los jueces en la aplicación de la ley dentro de la organización judicial chilena”, en Revista Chilena de Derecho, Vol. 40 No 2.

* Dentr, Vittorio (2004): La giustizia civile (Bolonia, Il Mulino).

* FAIRÉN, Víctor (1999): "Independencia constitucional y desarrollos de independencia de los jueces españoles”, en AA.VV., L’indipendenza della giustiziaoggi. Judicial Independence today (Milán, Giuffrè).

* Ferrara, Ettore (2001): “I mecanismo elettorali” en Mazzamuto, Salvatore (editor), Il Consiglio Superiore della Magistratura. Aspetti costituqionali e prospettive di riforma (Turín, Giappichelli).

* GaLvis, Fernando (2012): La Constitución política de 1991. Balance de veinte años (Bogotá, Temis).

* Gustapane, Antonello (1999): L'autonomia e l'indipendenza della magistratura ordinaria nel sistema costiturionale italiano (Milán, Giuffrè).

* Henao, Javier (2004): Panorama del derecho constitucional colombiano (Bogotá, Temis, primera edición).

* Horvitz, María Inés (2007): “Independencia de los jueces y estructura judicial”, en Couso, Javier y Atria, Fernando (edits.): La judicatura como organización (Santiago de Chile, Expansiva-Instituto de Estudios Judiciales).

* LuCAs Murillo de la Cueva, Pablo (2012): Reflexiones sobre la reforma del Consejo General del Poder Judicial (Madrid, Fundación Ciudadanía y Valores).

* Meniconi, Antonella (2012): Storia della magistratura italiana (Bolonia, Il Mulino).

* Moreno Catena, Víctor et. al (2005): Manual de organización judicial (Valencia, Tirant lo Blanch).

* Mortara, Lodovico (1992): Lo Stato moderno e la giustizia (Nápoles, Edizioni Scientifiche Italiane).

* Olano, Hernán (2004): Derecho constitucional orgánico. Estructura y funciones del Estado (Bogotá, ediciones doctrina y ley).

* Ollero, Andrés (2012): El Consejo General del Poder Judicial español: Independencia y autogobierno (Madrid, Fundación Ciudadanía y Valores).

* Pagliuca, Doménico (2013): "Il principio di indipendenza della magistratura", en Graziano, Nicola (editor): Ordinamento giudižiario (Roma, Dike giuridica editrice). 
* Pederzoli, Patrizia (2004): "Magistratura e politica: quale coabitazione?", en Gambino, Silvio (editor), La Magistratura nello Stato costituzionale. Teoria edesperienze a confronto (Milán, Giuffrè).

* Pepino, Livio (2009): "Relazione conclusiva", en Campanelli, Giusseppe (editor): Controllare i giudici? (cosa, chi, come, perché). Atti del convegno di studi - Lecce, febbraio 2008 (Turín, Giappichelli).

* PÉrez-Cruz, Agustín (2013): Constitución y Poder Judicial (Santiago de Compostela, Andavira editora).

* Pizzorusso, Alessandro (1990): L’organizzazione della giustizia in Italia (Turín, Einaudi).

* (1999): "Medio siglo de Poder Judicial en Italia", en AA.VV, La experiencia jurisdiccional: del Estado legislativo de derecho al Estado constitucional de derecho (Madrid, Consejo General del Poder Judicial).

* (2009): "Relazione introduttiva", en Campanelli, Giusseppe (editor), Controllare i giudici? (cosa, chi, come, perché). Atti del convegno di studi - Lecce, febbraio 2008 (Turín, Giappichelli) pp. $11-18$.

* Rebuffa, Giorgio (1993): La funcióne gindiziaria (Turín, Giappichelli).

* RIVAs, Israel (2011): El Consejo de la Judicatura Federal. Trayectoria y perspectivas (México D. F., Universidad Nacional Autónoma de México).

* Ruiz-Rico, Gerardo (2004): "Indipendenza e governo del potere giudiziario. Indipendenza e imparzialità giudiziaria sull'ordinamento costituzional espagnolo", en Gambino, Silvio (editor): La Magistratura nello Stato costituzionale. Teoriae desperienze a confronto (Milán, Giuffrè).

* SAlA, Pascual (2003): "El gobierno del Poder Judicial", en AA.VV, Constitución y Poder Judicial. XXV aniversario de la Constitución de 1978 (Madrid, Consejo General del Poder Judicial).

* SERGES, Giovanni (2001): "La potestà normativa", en Mazzamuto, Salvatore (editor): Il Consiglio Superiore della Magistratura. Aspetti costituqionali e prospettive di riforma (Turín, Giappichelli).

* Silvestri, Gaetano (2002): "I caratteri del "potere giudiziario", en Panizza, Saulle, Pizzorusso, Alessandro y Romboli, Roberto (edits.): Testi e questioni di ordinamento giudiziario e forense. Vol. I Antologia di scritti(Pisa, Edizioni Plus, Universitá di Pisa).

* Sorrentino, Federico (2009): “Governo dei giudici e giustizia amministrativa", en Campanelli, Giusseppe (editor): Controllare i giudici? (cosa, chi, come, perché). Atti del convegno di studi - Lecce, febbraio 2008 (Turín, Giappichelli).

* Taruffo, Michele (2001): "Le Corti Suprem eeuropee: acceso, filtri e selezione", en AA.VV.: Le Corti Supreme. Atti del convegno. Perugia 5 - 6 maggio 2000 (Milán, Giuffrè).

* VAllefuoco, Michele (2013): "Il Consiglio Superiore della Magistratura e glialtri organi di amministrazione", en Graziano, Nicola (editor): Ordinamento giudiziario (Roma, Dike giuridica editrice).

* VArgas, Juan Enrique (2007): “Alternativas para estructurar el gobierno judicial respetando la independencia de los jueces", en Couso, Javier y Atria, Fernando (edits.): La judicatura como organización (Santiago de Chile, Expansiva-Instituto de Estudios Judiciales).

* Vegas, Jaime (2012): Reflexiones sobre la reforma del Consejo General del Poder Judicial (Madrid, Fundación ciudadanía y valores).

* ZanOn, Nicoló y BIONDI, Francesca (2006): Il sistema costituzionale della magistratura (Bolonia, Zanichelli). 